\title{
Analisis Dampak Sosial Ekonomi dalam Pembangunan Bandara Yogyakarta International Airport (YIA) di Kabupaten Kulonprogo
}

\author{
Happy Susanto a,1,* \\ a Sekolah Tinggi Ilmu Administrasi (STIA) "AAN”, Yogyakarta \\ ${ }^{1}$ hpysusanto@gmail.com* \\ * corresponding author (08174849877)
}

\section{ARTICLE INFO}

\section{Article History}

Received Desember 2019

Revised Januari 2020

Accepted Februari 2020

Keywords

YIA development

Kulonprogo airport

Social-economy impact

\section{ABSTRACT}

The development of Yogyakarta International Airport (YIA) in Kulonprogo, Daerah Istimewa Yogyakarta (DIY), is the intention of the central government and regional governments to increase economic growth, develop regional infrastructure, and develop the social life of the community. The development of the YIA is also expected to provide great benefits for the development of tourism, so an air transportation infrastructure improvement is needed. The construction of this international airport has had socio-economic impacts on the lives of surrounding communities, both positive and negative impacts. The purpose of this study is to understand and describe how the socio-economic impact of YIA Airport development and how the strategies can be carried out by the government to overcome the impact of the development. This research uses descriptive method with a qualitative approach to explore the meaning of a phenomenon that occurs. Data collection techniques carried out by observation, direct interviews, documentation, and triangulation, so that data and information can be obtained that support the purpose of the study.

\section{PENDAHULUAN}

Pembangunan Yogyakarta International Airport (YIA) di Kabupaten Kulonprogo, Daerah Istimewa Yogyakarta (DIY), menuai sejumlah permasalahan, terutama dari aspek sosial dan ekonomi bagi masyarakat sekitar. Pembangunan bandara bertaraf internasional ini menjadi sebuah kebutuhan yang sangat mendesak bagi masyarakat Yogyakarta mengingat infrastruktur bandara saat ini dirasa oleh banyak kalangan kurang memadai dan terjadi penurunan kualitas layanan. Pembangunan bandara yang menghabiskan luas lahan yang mencapai ribuan meter persegi itu pastinya memerlukan adaptasi yang bagus dan positif dari masyarakat sekitar.

Berdasarkan berbagai definisi tentang pembangunan, ada sebuah makna yang seakan sudah baku jika kita mendengar istilah ini, yakni bahwa pembangunan bertujuan untuk mengubah suatu keadaan menjadi lebih baik, sesuai dengan apa yang direncanakan. Menurut perspektif penyelenggara pembangunan, tujuan pembangunan adalah positif karena dianggap baik, pantas, dan harus dilaksanakan, namun pemahaman bisa menjadi berbeda menurut perspektif pihak yang lain, dalam hal ini terutama adalah pihak masyarakat yang terdampak.

Setiap pembangunan pastinya menghasilkan dampak, yakni suatu perubahan yang terjadi sebagai akibat dari adanya aktivitas, yang bersifat alamiah (Soemarwoto, 2001). Dalam konteks penelitian ini, pembangunan bandara adalah sebuah aktivitas yang memaksa terjadinya beberapa perubahan yang signifikan dan memberikan dampak bagi kehidupan masyarakat sekitar. Dampak yang terjadi meliputi semua aspek wilayah, baik yang bersifat lingkungan, sosial, maupun ekonomi. Dampak yang ditimbulkan dari aktivitas pembangunan bisa berupa dampak yang positif maupun dampak negatif, yang bersifat langsung maupun tidak langsung.

Pembangunan YIA merupakan agenda untuk merealisasikan pembangunan bidang sektoral yang terintegrasi dengan konsentrasi wilayah Pantai Selatan. Tertuang dalam Rencana Kerja Pembangunan 
Daerah Yogyakarta (2016: 390), tujuan dari pembangunan ini adalah untuk meningkatkan pertumbuhan ekonomi, pengembangan infrastruktur wilayah, dan pengembangan kehidupan sosial masyarakat. Berdasarkan Keputusan Menteri Perhubungan Republik Indonesia No. KP 1164 Tahun 2013 tentang Penetapan Lokasi Bandar Udara Kulonprogo Provinsi DIY, yang sudah diubah menjadi Keputusan Menteri Perhubungan RI No. KP 836 Tahun 2014, dan juga diperkuat dengan keputusan Gubernur Nomor 68/KEP/2015 Tanggal 31 Maret 2015 tentang Penetapan Lokasi Pembangunan untuk Pengembangan Bandara Baru di DIY, pembangunan YIA dipusatkan di Kecamatan Temon, Kabupaten Kulonprogo, dan sudah dimulai proses pembangunannya sejak 2013. Pembangunan ini membutuhkan luas lahan (tanah) sebesar 645,63 hektar yang meliputi tujuh desa terdampak, yakni Desa Sindutan, Desa Jangkaran, Desa Kebonrejo, Desa Glagah, dan Desa Temon, yang meliputi Temon Wetan dan Temon Kulon (http://jogjaprov.go.id).

Pembangunan bandara memberi dampak sosial ekonomi bagi kehidupan masyarakat ke depannya, baik secara positif maupun negatif. Bagi masyarakat yang sudah mendapatkan ganti rugi lahan, tidak mudah bagi mereka untuk mencari lahan pertanian dan perkebunan pengganti di tempat lain untuk memenuhi kebutuhan hidup mereka sehari-hari, mengingat mayoritas warga desa sekitar adalah bermata pencaharian sebagai petani. Meski begitu, keberadaan bandara ini bisa meningkat kehidupan ekonomi masyarakat sekitar jika mampu dimanfaatkan dengan sebaik-baiknya, namun harus didukung dengan adanya modal dana yang memadai, misalnya untuk membuat usaha ekonomi. Pembangunan bandara ini juga memberi dampak secara sosial sehingga tatanan kehidupan masyarakat bisa berubah seiring dengan perkembangan wilayah menjadi lebih padat, ramai, dan semakin maju. Oleh karena itu penelitian bertujuan untuk menganalisis tentang bagaimana dampak sosial ekonomi dalam pembangunan YIA tersebut sebagai sebuah permasalahan yang sedang hangat terjadi saat ini. Penelitian ini menggunakan skema Penelitian Dosen Pemula karena sebagai sebuah penelitian awal bagi dosen pemula.

\section{METODE PENELITIAN}

Penelitian ini merupakan sebuah penelitian analisis, yang dalam hal ini berfokus menganalisis tentang dampak sosial ekonomi pembangunan Bandara New Yogyakarta International Airport (NYIA) di Kabupaten Kulonprogo, DIY. Penelitian ini ingin mengetahui informasi serta melakukan analisis terhadap bagaimana dampak sosial ekonomi dari pembangunan bandara baru ini.

Metode penelitian yang digunakan adalah metode deskriptif, yakni sebuah prosedur pemecahan masalah dengan cara menggambarkan keadaan subyek atau obyek penelitian dengan didasarkan pada fakta-fakta yang tampak dan apa adanya (Nawawi, 1991). Dengan metode deskriptif, penelitian ini berharap bisa memahami dan menggambarkan subyek dan obyek penelitian beserta permasalahannya dengan interpretasi yang tepat. Adapun model pendekatan yang digunakan dalam penelitian ini adalah pendekatan kualitatif. Menurut John W. Cresswell (2012), penelitian kualitatif merupakan metode-metode untuk mengeksplorasi dan memahami meaning (makna) yang oleh sejumlah individu atau sekelompok orang dianggap berasal dari masalah sosial dan kemanusiaan.

Mengingat penelitian dengan pendekatan kualitatif melibatkan diri dengan obyek yang diteliti, melakukan pengumpulan data secara terbuka, dan berusaha mengeksplorasi sedalam mungkin, maka penelitian ini menggunakan strategi studi kasus. Stake (2005) memandang studi kasus sebagai strategi penelitian di mana di dalamnya peneliti menyelidiki secara cermat suatu program, peristiwa, aktivitas, proses, atau sekelompok individu.

Penelitian ini dilakukan di Kecamatan Temon, Kabupaten Kulonprogo, Daerah Istimewa Yogyakarta, sebagai lokasi dibangunnya Bandara New Yogyakarta International Airport YIA. Pengumpulan data penelitian ini menggunakan strategi observasi kualitatif. Peneliti terjung ke lapangan untuk mengamati bagaimana dampak sosial ekonomi pembangunan YIA. Pengamatan dilakukan dengan tipe nonpartian/pengamat sebagai partisan. Untuk memperkaya data, peneliti juga akan melakukan wawancara secara langsung dengan partisipan untuk mendapatkan pandangan atau opini dari para partisipan.

\section{Perkembangan Pembangunan Yogyakarta International Airport}

Pembangunan memiliki pengertian, yaitu membuat kehidupan yang lebih baik untuk setiap orang. Untuk sebagian besar orang pada masa kini, pembangunan dikatakan berhasil apabila sudah terpenuhinya 
kebutuhan-kebutuhan dasar hidup, seperti pangan dan kesehatan, ditambah dengan adanya rasa aman, mendapat pelayanan yang adil, dan martabat yang dihargai. Namun, sebagai suatu proses, pembangunan tidak melulu berujung pada hasil yang semestinya, yaitu perubahan menuju pada situasi kemajuan.

Menurut Mansour Fakih (2006:10), pembangunan adalah sebuah kata benda netral yang digunakan untuk menjelaskan proses dan usaha untuk meningkatkan kehidupan sosial, ekonomi, politik, budaya, dan infrastruktur masyarakat, dan sebagainya. Sementara itu, dalam pandangan Zaini Rohmad (2016:39), secara luas pembangunan dipahami sebagai suatu proses perbaikan yang berkesinambungan atas suatu masyarakat atau sistem sosial secara keseluruhan menuju kehidupan yang lebih baik atau lebih manusiawi. Dengan demikian, pada hakikatnya, pembangunan mencerminkan perubahan total suatu masyarakat atau penyesuaian sistem sosial secara keseluruhan, tanpa mengabaikan keragaman kebutuhan dasar dan keinginan individu atau kelompok sosial yang ada di dalamnya.

Pembangunan (development) merupakan sebuah teori yang lahir dari fakta modernitas. Modernitas, yang berasal dari peradaban Barat, mengedepankan rasionalitas dengan tujuan untuk bisa mengubah dunia menuju arah yang lebih baik (Peet \& Hartwick, 2009:1-2). Pembangunan sebenarnya adalah konsekuensi logis dari fenomena globalisasi yang seiring perkembangan waktu, definisinya lebih diasosiasikan dengan pertumbuhan. Karena itu, pembangunan seperti pisau bermata dua, yang di satu sisi dapat memberi manfaat, namun di sisi lain memberi dampak yang negatif jika tidak diantisipasi dan dikelola dengan baik atau jika pembangunan hanya dikuasai oleh kelompok tertentu.

Arief Budiman, di dalam bukunya Teori Pembangunan Dunia Ketiga (1995), menjelaskan ada lima pendekatan untuk mengukur pembangunan. Pertama, kekayaan rata-rata. Dalam pendekatan ini, pembangunan masyarakat dikatakan berhasil apabila pertumbuhan ekonomi mengalami peningkatan. Untuk mengukur produksi rata-rata setiap orang di sebuah negara, digunakan metode Gross National Product (GNP) dan Gross Domestic Product (GDP) yang dibagi dengan jumlah penduduk.

Kedua, pemerataan ketiga. Pendekatan ini mengkritik pendekatan yang pertama karena kekayaan rata-rata itu hanya dinikmati segilintir orang, padahal sebagian besar masyarakat tidak bisa menikmati pertumbuhan sehingga mereka tetap hidup dalam garis kemiskinan. Pendekatan ini menekan pentingnya pemerataan terhadap hasil-hasil dari pertumbuhan ekonomi. Cara yang digunakan untuk mengukur pemerataan ini adalah dengan melihat berapa persen dari GNP yang diraih $40 \%$ penduduk miskin, berapa persen dari $40 \%$ persen yang dinikmati penduduk menengah, dan berapa persen dari $20 \%$ persen yang dinikmati penduduk kaya. Ada cara lain untuk mengukur pemerataan, yakni dengan menggunakan indeks gini, dengan skala 0-1. Jika indeks gini sama dengan satu, maka terjadi ketimpangan maksimal, namun jika 0 berarti tidak ada ketimpangan.

Ketiga, kualitas hidup. Pendekatan ini lebih menekankan pada kesejahteraan penduduk, tidak hanya dari sudut pandang ekonomi. Tolok ukur kesejahteraan penduduk bisa menggunakan PQLI (Physical Quality of Life Index), dengan tiga indikator, yaitu: rata-rata harapan hidup, rata-rata jumlah kematian bayi, dan rata-rata persentase buta huruf.

Keempat, kerusakan lingkungan hidup. Aspek lingkungan hidup juga dianggap penting dalam pembangunan. Pendekatan pertumbuhan dan pemerataan akan dianggap tidak berarti apa-apa jika ternyata pembangunan justru merusak lingkungan hidup. Menurut pendekatan ini, ketika lingkungan hidup rusak, maka masa depan masyarakat lokal menjadi terancam.

Kelima, keadilan sosial dan kesinambungan. Pendekatan ini merupakan gabungan antara pendekatan pemerataan dan pendekatan lingkungan hidup. Pendekatan ini sebenarnya ingin menegaskan bahwa pembangunan baru dikata berhasil apabila pemeretaan dapat terwujud, tapi sekaligus tidak merusak lingkungan sekitar.

Bandara Internasional Yogyakarta atau Yogyakarta International Airport (YIA), yang sebelumnya bernama New Yogyakarta International Airport (NIY), mulai beroperasi pada 6 Mei 2019. Tercatat sejak dibukanya penerbangan komersial perdana hingga 31 Agustus 2019, YIA telah melayani sebanyak 96 ribu penumpang. Menurut pernyataan Direktur Utama PT Angkasa Pura I (Persero) Faik Fahmi, terjadi peningkatan penumpang di YIA sebesar 40 persen. Pada Juli 2019, YIA melayani 27.585 penumpang dan mengalami peringkatan besar dengan jumlah 38.646 penumpang sepanjang Agustus 2019 (http://www.liputan6.com). 
Keberadaan YIA tidak diragukan sudah menjadi kebutuhan bagi masyarakat Yogyakarta dan sekitarnya. Bandara Adisutjito tidak bisa menampung jumlah penumpang pesawat yang kian hari kian meningkat. Proses pembangunan YIA ini memakan waktu bertahun-tahun lamanya, mulai dari persiapan, sosialisasi kepada masyarakat, pembebasan lahan, hingga proyek pembangunan fisik pada saat ini. Pembangunan YIA ditargetkan akan selesai seratus persen pada akhir tahun ini sehingga bisa dioperasikan secara penuh pada awal tahun 2020. Pada September 2019, proyek pembangunan bandara internasional telah mencapai tahapan 82 persen.

Berdasarkan Keputusan Gubernur Nomor 68/KEP/2015 Tanggal 31 Maret 2015 tentang Penetapan Lokasi Pembangunan untuk Pengembangan Bandara Baru di DIY, pembangunan YIA dipusatkan di Kecamatan Temon, Kabupaten Kulonprogo, dan sudah dimulai proses pembangunannya sejak 2013. Pembangunan ini membutuhkan luas lahan (tanah) sebesar 645,63 hektar yang meliputi lima desa terdampak, yakni Desa Glagah, Desa Palihan, Desa Kebonrejo, Desa Sindutan, dan Desa Jangkaran. Desa Glagah dan Desa Palihan merupakan dua desa paling terdampak karena banyak lahan warga yang tergusur akibat proyek pembangunan bandara ini.

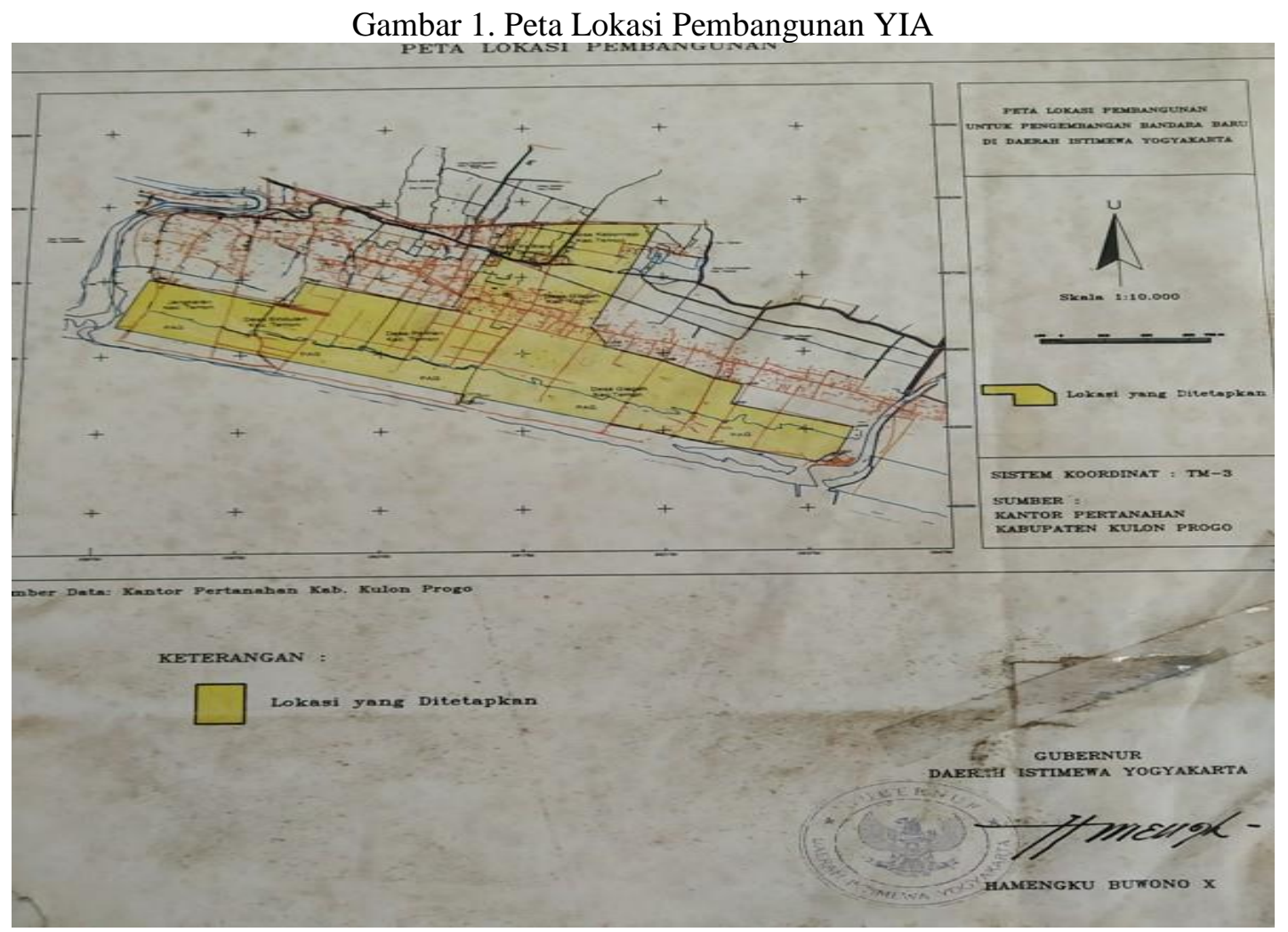

Sumber: Kantor Pertanahan Kabupaten Kulonprogo, 2015

Pembangunan YIA diperkirakan menelan biaya sekitar Rp 6 triliun. Bandara ini memiliki terminal dengan luas 106.500 meter persegi dengan kapasitas 10 juta penumpang setiap tahun. YIA juga akan memiliki hangar seluas 371.125 meter persegi sehingga bisa menampung 28 unit pesawat (http://www.merdeka.com). Dengan besarnya proyek pembangunan YIA, berbagai pihak harus terlibat, termasuk pemerintah lokal setempat setingkat kecamatan dan desa, demikian halnya masyarakat pada umumnya. Masyarakat adalah pihak paling terdampak dari pembangunan sehingga sehingga apa yang menjadi kebutuhan dan harapan mereka tidak bisa diabaikan begitu saja.

Proses pembangunan YIA berlangsung bertahun-tahun, sebelum akhirnya proses pelaksanaan pembangunan fisik dimulai sejak awal tahun 2018. Ada beberapa tahapan yang harus dilalui:

1. Ijin Penetapan Lokasi (IPL) dari Kementerian Perhubungan Republik Indonesia, melalui Direktorat Jenderal Perhubungan Udara, ditetapkan pada awal tahun 2014. Pihak pemerintah memberikan ijin kepada pengelola PT Angkasa Pura I. PT Angkasa Pura I sudah menyerahkan data pendukung administrasi proyek, seperti survei topografi, penyelidikan tekstur tanah, dan keselamatan operasional penerbangan untuk kawasan bandara. 
2. PT Angkasa Pura I kemudian melakukan kerjasama dengan Pemerintah Provinsi DIY, Pemerintah Kabupaten, dan Kecamatan, yang diikuti dengan sosialisasi terkait IPL yang sudah mendapat restu dari Kementerian Perhubungan.

3. Dilakukan pemetaan Penetapan Lokasi (PL), yakni pendataan terhadap lokasi rencana pembangunan bandara yang baru.

4. Konsultasi publik, dengan bertujuan untuk meminta pendapat dari warga masyarakat desa-desa terdampak. Konsultasi publik dilakukan sebanyak tiga kali.

5. Dilakukan pengukuran dan pencatatan terhadap jalan (sifatnya definitif).

6. Penilaian (appraisal), dengan hasil apakah setuju atau tidak setuju.

7. Verifikasi data lapangan, untuk mengoreksi apakah datang bisa disepakati atau tidak.

8. Ijin Penetapan Lokasi (IPL) Gubernur DIY yang pertama turun, yakni pada tahun 2016.

9. Pendataan lahan-lahan terdampak yang dilakukan oleh Badan Pertanahan Nasional (BPN) Kulonprogo, yang hasilnya disampaikan kepada masyarakat.

10. Tim appraisal turun ke lapangan untuk melakukan pengukuran secara langsung, yang hasilnya disampaikan kepada masyarakat terkait data berapa jumlah ganti rugi yang didapat dari pembebasan lahan. Dasar yang digunakan untuk menentukan jumlah ganti rugi adalah hasil pengukuran, bukan sertifikat, sehingga sering terjadi perbedaan luas lahan antara hasil pengukuran dan sertifikan. Meski begitu, masyarakat rata-rata bisa menerima kenyataan tersebut.

11. Pembangunan mulai dilakukan pada awal tahun 2018.

Terkait dengan konsultasi publik, pihak pemerintah kecamatan dan pemerintah desa bertindak sebagai fasilitator untuk menghubungkan pelaksana proyek (PT Angkasa Pura I), Pemerintah Provinsi DIY, dan masyarakat. Pihak kecamatan dan desa hanya memfasilitasi tempat untuk pertemuan kegiatan sosialisasi dan konsultasi publik karena mereka tidak memiliki tugas, pokok, dan fungsi (tupoksi) dalam proyek pembangunan YIA.

Jelang proyek pembangunan YIA, sering terjadi demonstrasi yang dilakukan sejumlah kelompok masyarakat. Demontrasi yang terjadi tidak lepas dari penolakan sejumlah warga dengan rencana proyek pembangunan YIA, terutama dari Desa Glagah dan Desa Palihan, sebagai dua desa paling terdampak. Para warga yang menyuarakan aspirasi itu tidak rela jika tanah kelahiran mereka dan sumber penghidupan selama ini "direbut" akibat adanya pembangunan infrastruktur bandara. Mereka berharap kelestarian sosial dan alam tetap terjaga, tidak terusik dengan modernisasi. Beberapa demonstrasi juga dilakukan oleh warga yang menuntut ganti rugi lahan yang layak. Berdasarkan pengamatan peneliti akhirakhir ini, sudah tidak ada lagi aksi-aksi demonstrasi sehingga terkesan suasana semakin kondusif.

Pelaksana Proyek Pembangunan YIA kini fokus pada program-program pemberdayaan Masyarakat (Community Development), yang menjadi bagian dari Corporate Social Responsibility (CSR), sejak pembangunan fisik berlangsung pada awal tahun 2018. Berdasarkan data dari Badan Pemberdayaan Masyarakat (BPM) PT Angkasa Pura I, sejumlah program CSR yang dilaksanakan sepanjang tahun 2018 adalah pelatihan bahasa Inggris, pelatihan mesin pendingin, pelatihan las SMAW, pelatihan mekanikal listrik, pelatihan pertukangan batu dan kayu, bantuan beasiswa pendidikan, penguatan PAUD, perlindungan dan pemberdayaan warga difabel, perlindungan dan pemberdayaan kelompok lansia, pemberdayaan peternak sapi, pengembangan agribisnis, dan pemberdayaan nelayan. Beberapa kegiatan adalah hasil kerjasama dengan Balai Latihan Kerja (BLK) Kulonprogo, di antaranya pelatihan bahasa Inggris, pelatihan mesin pendingin, latihan las SMAW, pelatihan mekanikal listrik, dan pelatihan pertukangan batu dan kayu. 
Tabel 1. Pelaksanaan Program CSR Tahun 2018 YIA

\begin{tabular}{|c|c|c|c|c|c|c|}
\hline NO & KEGIATAN & PESERTA & VENDOR & TEMPAT & WAKTU & $\begin{array}{c}\text { KETE- } \\
\text { RANGAN }\end{array}$ \\
\hline 1. & $\begin{array}{l}\text { Pelatihan Bahasa Inggris } \\
\text { Gelombang } 1\end{array}$ & 40 & BLK & HD/BPM & $\begin{array}{c}11 \text { Juli-14 } \\
\text { Agustus } 2018\end{array}$ & Terlaksana \\
\hline 2. & $\begin{array}{l}\text { Pelatihan Bahasa Inggris } \\
\text { Gelombang II }\end{array}$ & 40 & BLK & $\mathrm{HD} / \mathrm{BPM}$ & $\begin{array}{l}20 \text { Agustus- } 25 \\
\text { September } 2018\end{array}$ & Terlaksana \\
\hline 3. & $\begin{array}{l}\text { Pelatihan Bahasa Inggris } \\
\text { Gelombang III }\end{array}$ & 40 & & HD/BPM & $\begin{array}{l}27 \text { September- } \\
31 \text { Oktober } \\
2018\end{array}$ & Terlaksana \\
\hline 4. & $\begin{array}{l}\text { Pelatihan Bahasa Inggris } \\
\text { Gelombang IV }\end{array}$ & 40 & & $\mathrm{HD} / \mathrm{BPM}$ & $\begin{array}{c}2 \text { November-7 } \\
\text { Desember } 2018\end{array}$ & Terlaksana \\
\hline 5. & $\begin{array}{l}\text { Pelatihan Mesin } \\
\text { Pendingin }\end{array}$ & & BLK & BLK & $\begin{array}{c}8 \text { Oktober-10 } \\
\text { November } 2018\end{array}$ & Terlaksana \\
\hline 6. & Pelatihan Las SMAW & & BLK & BLK & $\begin{array}{c}\text { 10 Desember } \\
\text { 2018-11 Januari } \\
2019\end{array}$ & Terlaksana \\
\hline 7. & $\begin{array}{l}\text { Pelatihan Mekanikal } \\
\text { Listrik }\end{array}$ & & BLK & BLK & $\begin{array}{c}\text { Data tidak } \\
\text { terdeteksi }\end{array}$ & Terlaksana \\
\hline 8. & $\begin{array}{l}\text { Pelatihan Pertukangan } \\
\text { Batu dan Kayu }\end{array}$ & & BLK & BLK & $\begin{array}{c}12 \text { November- } \\
17 \text { Desember } \\
2018 \\
\end{array}$ & Terlaksana \\
\hline 9. & $\begin{array}{l}\text { Bantuan Beasiswa } \\
\text { Pendidikan (SD, SMP, } \\
\text { SMA) }\end{array}$ & 238 & & & $\begin{array}{l}\text { 6-24 Agustus } \\
2018\end{array}$ & \\
\hline 10. & Penguatan PAUD & 17 & & & $\begin{array}{l}\text { 10-31 Agustus } \\
2018\end{array}$ & \\
\hline 11. & $\begin{array}{l}\text { Perlindungan dan } \\
\text { Pemberdayaan Warga } \\
\text { Difabel }\end{array}$ & & Swakelola & & $\begin{array}{l}15 \text { Agustus-12 } \\
\text { Oktober } 2018\end{array}$ & \\
\hline 12. & $\begin{array}{l}\text { Perlindungan dan } \\
\text { Pemberdayaan Kelompok } \\
\text { Lansia }\end{array}$ & & Swakelola & & $\begin{array}{l}15 \text { Agustus-12 } \\
\text { Oktober } 2018\end{array}$ & \\
\hline 13. & $\begin{array}{l}\text { Pemberdayaan Peternak } \\
\text { Sapi }\end{array}$ & & Swakelola & & $\begin{array}{c}1 \text { Oktober-14 } \\
\text { Desember } 2018\end{array}$ & \\
\hline 14. & Pengembangan Agribisnis & & Swakelola & & $\begin{array}{c}1 \text { Oktober-30 } \\
\text { November } 2018\end{array}$ & \\
\hline 15. & Pemberdayaan Nelayan & & Swakelola & & $\begin{array}{l}3 \text { September-31 } \\
\text { Oktober } 2018\end{array}$ & \\
\hline
\end{tabular}

Sumber: BPM YIA, 2019.

Tabel 2. Pelaksanaan Program CSR Tahun 2019 YIA

\begin{tabular}{|l|l|l|l|l|l|l|}
\hline NO & KEGIATAN & & VENDOR & TEMPAT & WAKTU & $\begin{array}{l}\text { KETE- } \\
\text { RANGAN }\end{array}$ \\
\hline 1. & $\begin{array}{l}\text { Perluasan Kesempatan } \\
\text { Berusaha }\end{array}$ & & Non-BLK & & $\begin{array}{l}\text { 2 Januari-29 } \\
\text { Maret 2019 }\end{array}$ & \\
\hline 2. & Pengembangan Pariwisata & & Non-BLK & & $\begin{array}{l}5 \text { Maret-27 } \\
\text { April 2019 }\end{array}$ & $\begin{array}{l}12 \text { Maret-25 } \\
\text { Mei } 2019\end{array}$ \\
\hline 3. & $\begin{array}{l}\text { Perluasan Kesempatan } \\
\text { Pendukung Operasi } \\
\text { Bandara }\end{array}$ & & Non-BLK & & & \\
\hline
\end{tabular}




\section{Analisis Dampak Sosial Ekonomi Pembangunan Yogyakarta International Airport}

Dampak disebut impact dalam bahasa Inggris, yang bersinonim dengan kata effect (akibat) dan consequences (akibat). Menurut Kamus Besar Bahasa Indonesia (http://kbbi.web.id), dampak bisa diartikan sebagai pengaruh kuat yang mendatangkan akibat (baik negatif maupun positif). Dalam konteks pembangunan yang berdampak, artinya bahwa pembangunan bisa berpengaruh terhadap sebab-akibat dari ditimbulkannya aktivitas pembangunan.

Dampak bisa terdiri atas empat jenis. Pertama, dampak positif, yakni dampak yang dianggap baik oleh penyelenggara pembangunan atau pihak lain. Kedua, dampak negatif, yakni dampak yang tidak dianggap baik oleh penyelenggara pembangunan atau pihak lain. Ketiga, dampak yang disadari, yakni dampak yang direncanakan oleh penyelenggara pembangunan dan diketahui atau disadari akan terjadi (dalam sosiologi disebut sebagai fungsi manifes). Keempat, dampak yang tidak disadari, yakni dampak yang tidak direncanakan oleh penyelenggara pembangunan sehingga dampaknya tidak diketahui atau tidak disadari (dalam sosiologi disebut sebagai fungsi laten). Untuk mengetahui dampak laten diperlukan kesadaran sosiologis, yakni bahwa ada realitas sosial di balik realitas sosial itu sendiri (Afrizal, 2006).

Pembangunan sudah pasti memberi dampak perubahan sosial. Perubahan sosial, menurut Selo Soemardjan, seperti dikutip Djazifah (2012:5), adalah segala perubahan yang terjadi pada lembagalembaga kemasyarakatan dalam suatu masyarakat yang pada akhirnya mempengaruhi sistem sosial mereka, termasuk di dalamnya adalah perubahan nilai, sikap, dan pola perilaku di antara kelompokkelompok dalam masyarakat. Perubahan sosial ini terutama memberi dampak sosial dan dampak ekonomi.

Dampak sosial adalah suatu bentuk akibat atau pengaruh yang terjadi pada masyarakat, baik karena kejadian itu mempengaruhi masyarakat atau hal-hal lain di dalam masyarakat (Fardani, 2012:6). Dampak sosial bisa ditandai dengan empat indikator, yakni perubahan sistem sosial, nilai-nilai individu dan kolektif, perilaku hubungan sosial, gaya hidup masyarakat, dan struktur masyarakat. Adapun dampak ekonomi terdiri dari dampak terhadap pendapatan, dampak terhadap aktivitas ekonomi, dan dampak terhadap pengeluaran (Cohen, dalam Dwi, 2015:21).

Pembangunan YIA memiliki dampak sosial ekonomi, baik yang bersifat positif maupun negatif. Secara umum, keberadaan YIA akan memberikan dampak yang positif bagi peningkatan ekonomi masyarakat. Selain Pemerintah Provinsi DIY dan Pemerintah Kabupaten Kulonprogo akan mendapatkan keuntungan yang besar dari YIA, masyarakat di desa-desa terdampak juga merasakan dampak positifnya.

Berdasarkan wawancara dengan Agus Hidayat, Sekretaris Camat Temon, ada beberapa hal positif yang bisa dirasakan para warga sebagai dampak positif dari keberadaan YIA. Pertama, beberapa warga seperti orang kaya baru (OKB). Dengan mendapat uang ganti rugi (yang sebenarnya adalah ganti untung), para warga itu mendapat uang cukup banyak. Ada sebagian warga yang terkena kebijakan relokasi membeli tanah dan membangun rumah di tempat relokasi, ada juga warga yang membeli tanah di lokasi lain dan kemudian membangunnya, dan ada juga warga yang membeli rumah langsung. Meski uang mereka berkurang untuk membeli rumah, tapi mereka masih memiliki simpanan dana untuk investasi. Dengan demikian, dampak dari keberadaan YIA adalah bahwa harga tanah menjadi naik sehingga warga mendapat kentungan yang cukup berarti.

Kedua, mulai marak berdirinya beberapa perumahan, kontrakan, dan kos-kosan. Bagi warga yang "melek bisnis", keberadaan YIA bisa dimanfaatkan untuk mencari keuntungan finansial. Bidang papan adalah salah satu pilihan yang menarik. Tidak sedikit konsumen yang tertarik untuk membeli perumahan, atau menyewa kontrakan atau kos-kosan sebagai tempat tinggal permanen atau sementara (bagi pekerja proyek). Ketiga, bisnis rumah makan, catering, dan sejenisnya. Dengan semakin banyak orang yang lalu lalang di sekitar proyek pembangunan YIA, maka kebutuhan bidang sandang juga sangat penting. Karena itu, beberapa waga memutuskan untuk membuka bisnis atau usaha makanan, terutama untuk menyediakan kebutuhan pangan bagi para pekerja proyek atau orang-orang yang bekerja di dalam maupun luar lokasi bandara.

Agus Hidayat menyoroti terkait dampak negatif dari sisi sosial dengan keberadaan YIA. Menurutnya, dengan banyaknya pekerja, baik itu di dalam bandara maupun pekerja proyek, mulai tumbuh tempat hiburan, salah satunya terletak di Desa Palihan. Dengan keberadaan tempat hiburan ini, mentalitas dan moral masyarakat bisa berubah. Pak Sekcam itu juga menilai bahwa beberapa warga, karena 
memiliki uang yang cukup banyak, terpengaruh dengan gaya hidup yang berujung pada adanya kasus perceraian, bahkan kekerasan dalam rumah tangga (KDRT). Dampak-dampak sosial semacam itu layaknya mendapat perhatian serius dari pemerintah dan kalangan pemuka agama.

Kabupaten Kulonprogo, khususnya Kecamatan Temon, akan mengalami perkembangan yang sangat pesat ke depannya, seiring dengan proyek pembangunan YIA yang ditargetkan akan selesai seratus persen pada akhir tahun ini. Menurut informasi yang disampaikan Nissi Wardoyo, Kaur Umum Desa Kebonrejo, sejumlah pusat bisnis akan didirikan di sekitar kawasan YIA. Pertama, Hotel Dafam dengan berlokasi di Desa Kebonrejo, yang letaknya persis di sebelah utara kantor PT PP. Hotel ini memiliki luas sekitar 4.000 meter, yang sebelumnya menjadi milik satu orang warga, namun sudah resmi dijual. Kedua, pom bensin dan restoran yang menjadi bagian dari Grup Ambar Ketawang, dengan berlokasi di Desa Kebonrejo, yang memiliki luas sekitar satu hektar. Ketiga, Hotel Ibis dan Hotel Novotel, yang masuk dalam satu grup Accord, dengan berlokasi di Desa Temon Kulon. Dua hotel ini memiliki luas sekitar satu hektar.

Dengan fakta itu, masyarakat di lima desa terdampak pembangunan YIA akan semakin menghadapi sejumlah masalah dengan keberadaan pusat-pusat bisnis tersebut. Sejumlah persoalan berpotensi muncul bagi kehidupan masyarakat sekitar. Dari sisi tingkat ekonomi, sebagian besar warga akan merasakan dampak positif dari keberadaan hotel-hotel tersebut, namun tidak sedikit dampak negatif yang ditimbulkan sehingga perlu ada antisipasi sejak dini. Pertama, sejumlah dampak sosial. Kepadatan penduduk dan perubahan tata kota sebagai akibat dari pembangunan YIA dan beberapa pusat bisnis bisa menimbulkan persoalan sosial karena terjadi "percampuran" antara penduduk asli dan pendatang. Dalam beberapa hal, "percampuran" ini memang bisa berdampak positif, yakni misalnya cara pandang atau cara hidup warga lokal menjadi semakin maju, namun jika tidak diantisipasi dengan tepat akan menimbulkan masalah-maslaah baru. Kasus narkoba, perselingkuhan, dan beberapa tindakan asusila bisa muncul apabila warga tidak siap dalam mengantisipasi dampak sosial perkembangan wilayan ke depan. Kedua, sejumlah masalah lingkungan. Keberadaan YIA dengan sejumlah fasilitas pendukungnya, ditambah dengan rencana pembangunan infrastruktur lanjutan serta pendirian sejumlah hotel, restoran, dan bangunan lainnya, pastinya akan berdampak pada kualitas air dan udara di lingkungan sekitar.

Untuk mengantisipasi dampak sosial dari keberadaan YIA, sejumlah program penyuluhan telah dilaksanakan oleh pemerintah, baik pemerintah daerah maupun pemerintah kecamatan/desa, bekerjasama dengan pihak PT Angkasa Pura I. Kegiatan-kegiatan penyuluhan itu dimaksudkan agar warga masyarakat memiliki modal pengetahuan dan terbangun kesadaran sosial agar mereka tidak kaget melihat perubahan cepat yang ada, tetapi bisa menyikapinya dengan hal-hal yang bersifat positif. Beberapa kegiatan tersebut di antaranya adalah: penyuluhan keagamaan dari Kementerian Agama dan penyuluhan pengarusutamaan gender lewat program Kecamatan Temon.

Karang Taruna Desa Kebonrejo berharap PT Angkasa Pura I (YIA) bisa memfasilitasi kegiatankegiatan CSR untuk memberikan kesiapan warga masyarakat dalam menyambut masa depan Kulonprogo sebagai kota metropolitan, yang diawali dengan pembangunan YIA. Salah satu tawaran yang diajukan karang taruna ini adalah kegiatan pelatihan wirausaha suvernir. Mengingat Kulonprogo akan menjadi destinasi wisata, para pemuda di desa berharap memiliki keterampilan usaha untuk membuat, mengembangkan, dan menjual produk-produk suvenir atau oleh-oleh bagi wisatawan atau penumpang YIA. Selain itu, mereka juga mengharapkan pelatihan-pelatihan lainnya, misalnya bahasa Inggris dan servis handphone. Terkait bahasa Inggris, kemampuan berbahasa internasional ini sangat penting agar warga desa di sekitar lokasi bandara bisa mendapat peluang bekerja, baik di dalam maupun luar YIA.

\section{Permasalahan Dampak Sosial Ekonomi dalam Pembangunan Yogyakarta International Airport}

Kabupaten Kulonprogo akan berkembang sebagai sebuah kota metropolitan yang baru. Selain bandara, daerah ini akan menjadi pusat pengembangan pariwisata ke depannya. Kementerian Pariwisata bersama Pemerintah Provinsi DIY sudah memiliki rencana untuk membuat program "Bedah Menoreh", yang akan menghubungkan YIA langsung ke Borobudur. Saat ini, sudah ada jalan kecil yang pada dasarnya adalah jalan perkampungan, namun ke depannya kemungkinan besar akan diperlebar. Selain itu, pembangunan infrastruktur yang akan digenjot di masa mendatang adalah pembangunan rel kereta api, yang akan menghubungan jalur rel dari Cilacap ke YIA dan Kota Yogyakarta. Pembangunan tol yang menghubungkan YIA dengan jalur selatan, termasuk ke arah barat (Cilacap) juga menjadi rencana prioritas pemerintah pusat. 
Warga masyarakat di lima desa terdampak tidak mendapat informasi memadai terkait roadmap pembangunan kota metropolitan tersebut. Sejak rencana pembangunan YIA mulai disosialisasikan kepada masyarakat, banyak warga yang sudah menangkap peluang tersebut dengan investasi jangka panjang, misalnya menjual tanah di saat harga terus naik atau membangun kos-kosan dan kontrakan. Hanya saja, dengan belum jelasnya RBTL, tidak sedikit warga yang bersifat "masih menunggu" untuk bersikap atas perkembangan wilayah saat ini. Berdasarkan penuturan sejumlah warga, mereka belum siap untuk mendirikan restoran, toko, atau bahkan kos-kosan/kontrakan, disebabkan karena mereka khawatir kalau tanah/lahan mereka akan menjadi sasaran perluasan untuk pembangunan infrastruktur, baik itu pelebaran jalan, jalur rel kereta api, jalan tol, dan kebutuhan-kebutuhan fasilitas pendukung YIA.

\section{KESIMPULAN}

Pembangunan YIA memberikan dampak sosial ekonomi bagi masyarakat sekitar, baik yang bersifat positif maupun negatif. Berdasarkan hasil penelitian, dampak positif pembangunan YIA sangat terlihat dari aspek-aspek ekonominya, yakni bertumbuhnya kegiatan-kegiatan perekonomian, seperti hotel, restoran, bisnis catering, perumahan, kontrakan, dan kos-kosan. Meski begitu, tidak sedikit dampak negatif dari keberadaan YIA ini dari aspek-aspek sosial karena masyarakat mengalami "pertukaran" budaya dan terciptanya kepadatan wilayah sebagai konsekuensi dari pembangunan infrastruktur.

\section{DAFTAR PUSTAKA}

Afrizal. 2006. Sosiologi Konflik Agraria; Protes-protes Agraria dalam Masyarakat Kontemporer. Padang: Universitas Andalas Press.

Budiman, Arief. 1997. Teori Pembangunan Dunia Ketiga. Gramedia: Jakarta.

Creswell, John W. 2012. Research Design: Pendekatan Kualitatif, Kuantitatif, dan Mixed, terj. Achmad Fawaid. Yogyakarta: Pustaka Pelajar.

----. 2014. Penelitian Kualitatif dan Desain Riset: Memilih di antara Lima Pendekatan, terj. Ahmad Lintang Lazuardi. Yogyakarta: Pustaka Pelajar.

Djazifah, Nur. 2013. Proses Perubahan Sosial di Masyarakat. Yogyakarta: Lembaga Penelitian dan Pengabdian kepada Masyarakat Universitas Negeri Yogyakarta.

Dwi P, Rahmat. 2015. Dampak Sosial Ekonomi dan Lingkungan Penambangan Batubara Ilegal di Desa Tanjung Lalang Kecamaran Tanjung Agung Kabupaten Muara Enim. Palembang: Universitas Sriwijaya.

Fakih, Mansour. 2006. Runtuhnya Teori Pembangunan dan Globalisasi. Yogyakarta: INSIST.

Fardani, Andi. 2012. Dampak Sosial Keberadaan PT Vale Indonesia Tbk terhadap Kehidupan Masyarakat (Studi Kasus Sorowako Kecamatan Nuha Kabupaten Luwu Timur). Makassar: Universitas Hasanuddin.

Ife, Jim dan Frank Tesoriero. 2016. Community Development: Alternatif Pengembangan Masyarakat di Era Globalisasi, terj. Sastrawan Manullang dkk, cet.III. Yogyakarta: Pustaka Pelajar.

Nawawi, Hadari. 1991. Metode Penelitian Bidang Sosial. Yogyakarta: Gadjah Mada University Press.

Peet, Richard \& Elaine Hartwick. 2009. Theories of Development: Contentions, Argument, Alternatives, Edisi Kedua. New York, London: The Guilford Press.

Pemerintah Provinsi DIY. 2016. Rencana Kerja Pembangunan Daerah Yogyakarta. Yogyakarta: Pemrov DIY.

Pieterse, Jan Nederveen. 2010. Development Theories: Deconstruction/Reconstruction, Edisi Kedua. Singapore, London: SAGE Publications.

Praditya, Ilyas Istianur. 2019. "Bandara Baru Yogyakarta Telah Layani 96 Ribu Penumpang," dalam https://www.liputan6.com/bisnis/read/4061273/bandara-baru-yogyakarta-telah-layani-96-ribupenumpang, diakses pada tanggal 12 Agustus 2019.

Putra, Idris Rusadi. 2014. "Bandara Internasional Kulonprogo Beroperasi pada 2017", dalam https://www.merdeka.com/uang/bandara-internasional-kulon-progo-beroperasi-pada-2017.html, diakses pada 12 September 2019.

Rohmad, Zaini. 2016. Sosiologi Pembangunan. Yogyakarta: Penerbit Ombak.

Soemarwoto, O. 2001. Ekologi, Lingkungan, dan Pembangunan. Jakarta: Djambatan 